\title{
Electrodeposition of Cu-Ni-P-W Composite on Al-6063 Substrate
}

\author{
M. Karunakaran ${ }^{1}$, M. Pugazhvadivu ${ }^{1}$, V. Gunasegaran², G. Gowtham ${ }^{3}$ \\ ${ }^{1}$ Dept. of Mechanical Engineering, Pondicherry Engineering College, Puducherry, India \\ ${ }^{2}$ Dept. of Mechanical Engineering, B.S.A.Crescent Institute of Science and Technology, Chennai - 48, India \\ ${ }^{3}$ Dept. of Quality, Easun-MR Tap Changers Pvt. Ltd., Puducherry, India \\ "Corresponding Author: karunakaran2610@gmail.com, Tel.: +91-98946-21196
}

Available online at: www.isroset.org

Received: 04/Jun/2018, Revised: 12/Jun/2018, Accepted: 22/Jun/2018, Online: 30/Jun/2018

\begin{abstract}
Thin layer coating of metals will improve the mechanical properties. Cu-Ni-P-W composite coatings were prepared by means of coating a thin film on the above of Al-6063 alloy. The aim of this composite coating is to improve the micromechanical properties such as sliding wear resistance and hardness of the Al. The microstructure of coated Al-6063 material was analyzed to determine such that properties. Due to slight increase in $\mathrm{P}$ and $\mathrm{W}$ content, the grain size refined gradually and the micro-hardness increased. However, on heat treatment, the composite coating exhibits improved wear resistance and better micro-hardness of the coated Al. Also the mechanical properties and tribological study of the coated material were analyzed by various tests such as wear, friction, hardness and surface roughness test and the results were compared and validated with $\mathrm{Cu}-\mathrm{Ni}-\mathrm{P}, \mathrm{Cu}-\mathrm{Ni}-\mathrm{P}-\mathrm{W}$ composite coatings. Hence the results shows that $\mathrm{Cu}-\mathrm{Ni}-\mathrm{P}-\mathrm{W}$ composites possess higher hardness, better corrosion resistance, good wear resistance, and low coefficient of friction.
\end{abstract}

Keywords-Al-6063, Electroplating, Cu-Ni-P-W composite coating, Micro-hardness, sliding-wear

\section{INTRODUCTION}

Surface modifications of $\mathrm{Al}$ and its alloys can offer a wide variety of mechanical, chemical, electrical properties and decorative finishing. Electroplating has gained commercial applications for components which need to have good wear and corrosion resistance [1], [2]. Aluminum-based metal matrix composites (AMMCs) have considerable attention because of their light weight, high corrosion resistance, high strength-stiffness combinations and wear resistance [3]. Electroplating is one of the useful techniques for making thin and thick surfaces on the above on Al substrate [4].In electroplating process, Al 6063 played a vital role in the automobile industries and architectural purpose in recent years [5]. The process of electro-deposition of Ni-P alloys has been extensively used in recent years due to their magnetic properties and corrosion resistance [6]. The significant attention on electroplating of nickel over the $\mathrm{Al}$ 6063 has increased extensively because the coating can eliminate the difficulties of uncoated Al to some extent [7]. This is the main intention why nickel plating is extensively used in automobile parts. Strong bonding of nickel on Aluminium is desirable for good wear resistance as well as mechanical properties of the engine parts [8], [9]. Nickel which has high hardness, corrosion resistance and tensile strength are the general advantage for a matrix material and it can disperse as both soft and hard reinforcement. When compared to pure metal or alloy, hardness, wear and corrosion resistance are improved in electro co-deposited metals or alloys [10].With the purpose of increasing the micro hardness, wear resistance, coefficient of friction, and surface roughness, corrosion resistance of the metal matrix composite coating are produced by electroplating and the fine particles of metallic and non-metallic materials along plating [11]-[13]. In electroplating nickel, phosphorus deposits are capable of providing wear resistance, coefficient friction and hardness particularly when phosphorus content is added and the properties of microstructures of electroplating coating depend on the amount of phosphorus [14]. Another effective method to improve the mechanical properties of electroplating composite coating is to add the binary electroplating nickel to form ternary composite coating such as Ni-P-W [15], Ni-P-Cu, Ni-W-Fe [16] Ni-W$\mathrm{TiO} 2$ [17]. Since very few data are available on the mechanical properties and tribological characteristics of electroplating ternary and quaternary system.

This experimental investigation aims at study is to obtain $\mathrm{Cu}$ Ni-P-W from nickel baths, studying the deposition and tribological of coating characteristics on ternary $\mathrm{Cu}-\mathrm{Ni}-\mathrm{P}$ and quaternary $\mathrm{Cu}-\mathrm{Ni}-\mathrm{P}-\mathrm{W}$ composite coating and also study the characteristics of coatings by using different analytical techniques such as SEM, EDX and examines the microhardness, surface roughness, wear resistance, and coefficient of friction, which has not been studied earlier. The paper is organized as follows: Section 2 gives the details of the 
experimental work, where completely discussed about materials and methods of electrodeposition, bath composition and coating parameter. We carryout various tests and discussed the results on different category to highlight the improved micromechanical properties after electrodeposition of $\mathrm{Cu}-\mathrm{Ni}-\mathrm{P}-\mathrm{W}$ composite on Al6063 substrate in section 3. Finally, we conclude the paper in section 4.

\section{EXPERIMENTAL WORK}

\subsection{Electro Co-deposition of Copper Coating}

The specimen of $30 \mathrm{~mm}$ x $10 \mathrm{~mm}$ x $10 \mathrm{~mm}$ of Al-6063 sample is cut from the aluminium bar by means of using milling machine and the sample are fine polished by using silicon carbide emery papers of P400,P600,P1000 and P2000 grit size [18]. The experimental activities such as specimen preparation, machining, polishing, and preparation of chemical solutions were done in the institute laboratory.
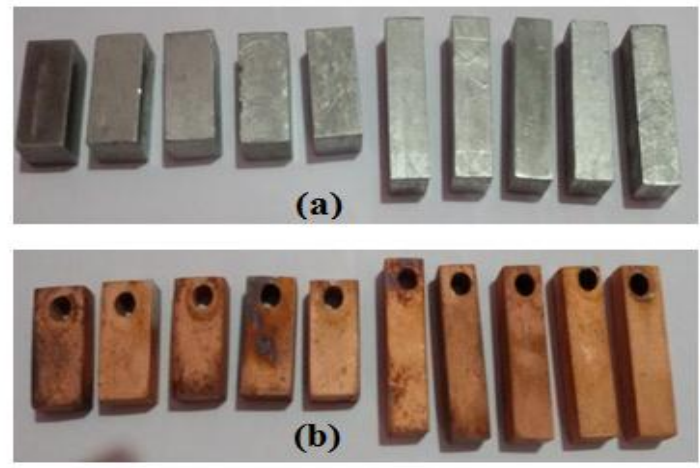

Fig. 1 (a) before copper coating on Al6063

(b) after coating of copper on Al6063

The polished substrates were first dipped in the acetone solution for 20 seconds to remove any residual alkali and then dipped into the ethanol to remove the oxide layer and finally washed with de-ionized water. The clean Al-6063 sample act as cathode and pure copper act as anode. The substrates were then layer of copper $(\mathrm{Cu})$ coated by a thin surface on the above Al 6063.The Copper having electrolytic composition of CuSo4-400 g/l of de-ionized water. In this $\mathrm{Cu}$-coating, the pure $\mathrm{Cu}$ rod act as anode and Al-6063 act as cathode. The current density of 40 $\mathrm{mA} /(\mathrm{cm})^{\wedge} 2$ and temperature of $60^{\circ} \mathrm{C}[18]$ were maintained throughout the plating process and the plating time was controlled for 15 minutes[18]. After electroplating, Al sample were rinsed in distilled water and dried in atmosphere air. Fig. 1 shows that the electro co-deposition before copper coating and after copper coating on aluminium 6063.

\subsection{Electro-deposition of Ni-P-W composite}

The electrochemical bath used for this experiment is also developed in the laboratory. The bath solutions were prepared by using analytical reagents and de-ionized water
[18]. The concentrations of the bath components for Ni-P-W alloy are shown in Table 1. Before the code position of Nickel, Phosphors with Tungsten is done [14], [15]. Nickel plates of dimensions are $30 \mathrm{~mm} \times 20 \mathrm{~mm} \times 5 \mathrm{~mm}$ is used as anode. It was cleaned properly to remove stains, oxide films, etc.

Table 1. Electroplating bath composition and parameters

\begin{tabular}{|l|l|}
\hline $\begin{array}{c}\text { Bath composition and } \\
\text { plating parameters }\end{array}$ & \multicolumn{1}{c|}{ Quantity } \\
\hline $\mathrm{NiSO}_{4} \cdot 6 \mathrm{H}_{2} \mathrm{O}$ & $250 \mathrm{~g} / \mathrm{L}$ \\
\hline $\mathrm{NiCl} 2 \cdot 6 \mathrm{H} 2 \mathrm{O}$ & $15 \mathrm{~g} / \mathrm{L}$ \\
\hline $\mathrm{NaCl}$ & $15 \mathrm{~g} / \mathrm{L}$ \\
\hline $\mathrm{H}_{3} \mathrm{BO}_{3}$ & $30 \mathrm{~g} / \mathrm{L}$ \\
\hline $\mathrm{H}_{3} \mathrm{PO}_{4}$ & $6 \mathrm{~g} / \mathrm{L}$ \\
\hline $\mathrm{Na}_{2} \mathrm{WO}_{4} \cdot 2 \mathrm{H}_{2} \mathrm{O}$ & $80 \mathrm{~g} / \mathrm{L}$ \\
\hline$T_{\text {Temperature }}$ & $60 \pm 2^{\circ} \mathrm{C}$ \\
\hline $\mathrm{pH}$ value & $3 \pm 0.5$ \\
\hline Time & $15 \mathrm{~min}$ \\
\hline Current rate & $40,50 \mathrm{~mA} / \mathrm{cm}^{2}$ \\
\hline Stir speed & $500 \mathrm{rpm}$ \\
\hline
\end{tabular}

During the plating process the electrolyte was agitated by mechanical impeller to maintain the uniform particulate concentration and to prevent the sedimentation of tungsten. The $\mathrm{pH}$ of electrolyte was maintained to $3.5 \pm 0.5$ [18] in all conditions. The coated samples as shown in Fig. 2 thereafter the substrate was degreased in acetone using ultrasonic cleaning device and washed twice using distilled water. To maintain a constant coating thickness, the time of coating was varied accordingly for each sample. The samples were then prepared accordingly for the requirement of each test.
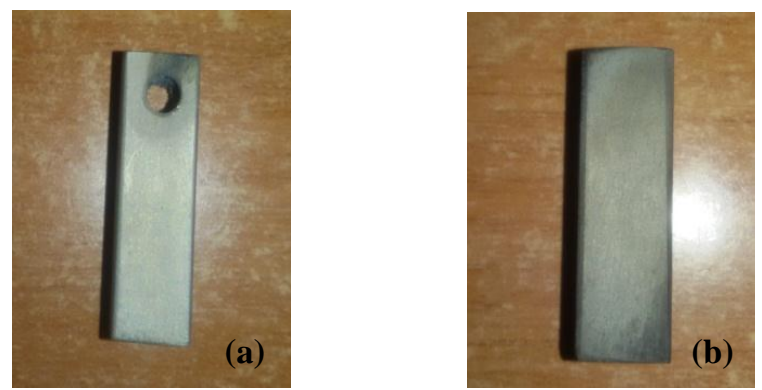

Fig.2. (a) Coating of $\mathrm{Cu}-\mathrm{Ni}-\mathrm{P}$ on $\mathrm{Al}$ substrate (b) Coating of $\mathrm{Cu}-\mathrm{Ni}-\mathrm{P}-\mathrm{W}$ on $\mathrm{Al}$ substrate

\section{RESUltS AND DISCUSSION}

\subsection{Cross sectional morphology}

A scanning electron microscope (SEM) microstructure shows the morphology of uniformly $\mathrm{Cu}-\mathrm{Ni}-\mathrm{P}$ and $\mathrm{Cu}-\mathrm{Ni}-\mathrm{P}-$ $\mathrm{W}$ coated on $\mathrm{Al}$ as shown in Fig.3. the composite coatings 
has been deposited. The comparison of SEM images indicates that $\mathrm{Cu}-\mathrm{Ni}-\mathrm{P}$ coating consist of uniform fine grained deposits (Fig 3. (a-b)) The SEM images of Cu-Ni-P$\mathrm{W}$ composite coating reveal the formation of uniform, well crystallized uniform and dense structure.

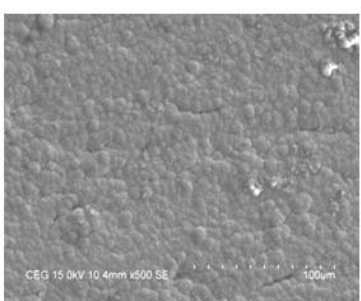

(a)

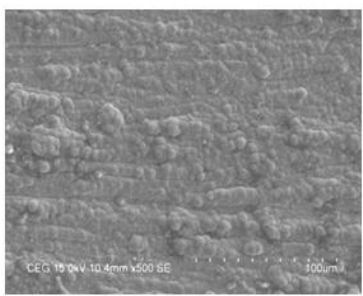

(c)

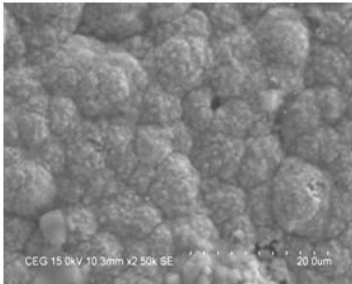

(b)

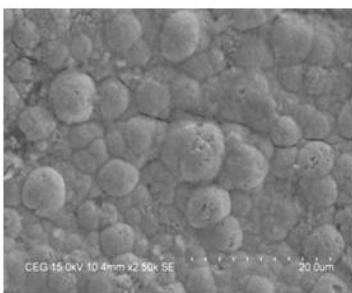

(d)
Fig.3. SEM surface morphology of Cu-Ni-P-W electrodeposited state

(a) $\mathrm{Cu}-\mathrm{Ni}-\mathrm{P}$ coated $\mathrm{Al} 100 \mu \mathrm{m}$, (b) $\mathrm{Cu}-\mathrm{Ni}-\mathrm{P}$ coated $\mathrm{Al} 20 \mu \mathrm{m}$, (c) $\mathrm{Cu}-\mathrm{Ni}-\mathrm{P}-\mathrm{W}$ coated $\mathrm{Al} 100 \mu \mathrm{m},(\mathrm{d}) \mathrm{Cu}-\mathrm{Ni}-\mathrm{P}-\mathrm{W}$ coated $\mathrm{Al}$ $20 \mu \mathrm{m}$

The presence of homogeneous fine globular structure which is distributed throughout is clearly noticed in Fig.3 (c-d). The good surface morphology of $\mathrm{Cu}-\mathrm{Ni}-\mathrm{P}-\mathrm{W}$ composite coating can be explained during the electro-co deposition process. The P-W particles adsorb coating in the bath under the high potential gradient.

\subsection{Elemental analysis}

The Energy-dispersive X-ray spectroscopy (EDX) is used for understanding the chemical characterization of samples. The EDS analysis is done on the coatings developed from the bath consisting the concentrations of copper, nickel, phosphorous, and sodium tungsten (tungsten ions) in order to capture the range of tungsten content in the coatings. Fig.4 shows the EDX spectra of the coated surface.

The EDX patterns of $\mathrm{Cu}-\mathrm{Ni}-\mathrm{P}$ and $\mathrm{Cu}-\mathrm{Ni}-\mathrm{P}-\mathrm{W}$ composite coating are presented in Fig 4.The existence of Ni observed that peak in the EDX pattern is due to the major part of $\mathrm{Ni}$ coated over a substrate.It is also Fig. 3 in addition to $\mathrm{Ni}$ and $\mathrm{P}$ peaks, sodium tungstate (W) also appeared in the EDX pattern which confirms the co-deposition of copper $(\mathrm{Cu})$ particles into Ni-P-W matrix. The result suggests the sodium tungstate can be successfully co-deposited in $\mathrm{Cu}-\mathrm{Ni}-\mathrm{P}$ coating.
Table 2. Quantitative result of EDS analysis

\begin{tabular}{|c|c|c|c|}
\hline Element & Net Counts & Weight \% & Atom \% \\
\hline $\mathrm{O}$ & 12816 & 16.21 & 42.9 \\
\hline $\mathrm{P}$ & 820 & 0.74 & 1.02 \\
\hline $\mathrm{Cu}$ & 0 & 0 & 0 \\
\hline $\mathrm{Cu}$ & 970 & 8.2 & 6.3 \\
\hline $\mathrm{Ni}$ & 16654 & 60.10 & 42.0 \\
\hline $\mathrm{Ni}$ & 63763 & 7.01 & 8.0 \\
\hline $\mathrm{W}$ & 483 & 7.74 & 1.78 \\
\hline $\mathrm{W}$ & 15118 & -- & -- \\
\hline \multicolumn{2}{|c|}{ Total } & 100 & 100 \\
\hline
\end{tabular}

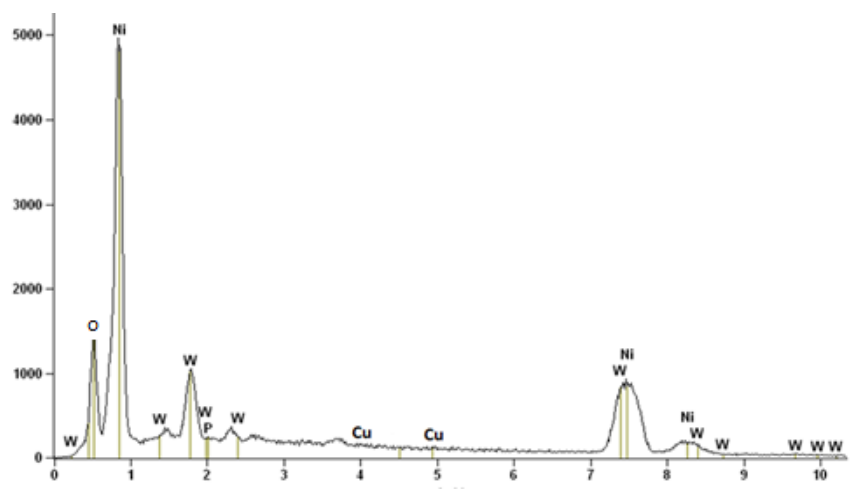

Fig.4. EDS analysis of coating in as electrodeposited state on Al substrate $\mathrm{Cu}-\mathrm{Ni}-\mathrm{P}-\mathrm{W}$

\subsection{Surface Roughness}

The surface roughness of specimen was measured using Taylor Hobson surface roughness tester for an evaluation length of $4 \mathrm{~mm}$ with measuring cut-of $0.8 \mathrm{~mm}$. By comparing the surface roughness profiles of both the $\mathrm{Cu}-\mathrm{Ni}$ $\mathrm{P}$ and $\mathrm{Cu}-\mathrm{Ni}-\mathrm{P}-\mathrm{W}$ coating, it can be noticeed that the surface of Cu-Ni-P coating is quit smooth [14]. The surface roughness $(\mathrm{Ra})$ of $\mathrm{Cu}-\mathrm{Ni}-\mathrm{P}$ coated $\mathrm{Al}$ found as $\mathrm{Ra}=1.37 \mu \mathrm{m}$ $(\mathrm{Rz}=10.9 \mu \mathrm{m})$ and $\mathrm{Cu}-\mathrm{Ni}-\mathrm{P}-\mathrm{W}$ found as $\mathrm{Ra}=2.16 \mu \mathrm{m}(\mathrm{Rz}=$ $12.2 \mu \mathrm{m})$ respectively. The surface roughness value is considerably high when compared with $\mathrm{Cu}-\mathrm{Ni}-\mathrm{P}$.

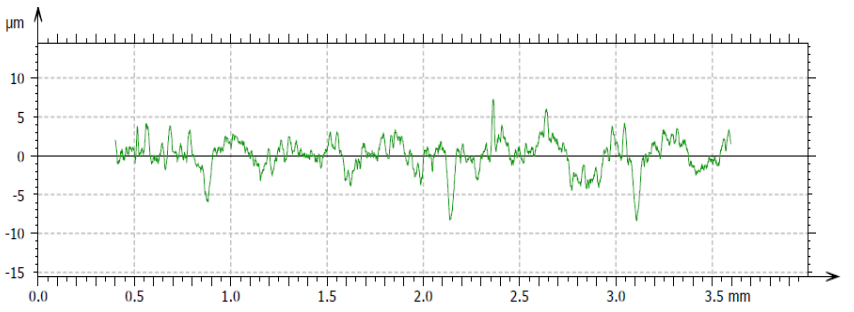

Fig. 5.(a) Surface roughness profile of $\mathrm{Cu}-\mathrm{Ni}-\mathrm{P}$ coated $\mathrm{Al}$ 


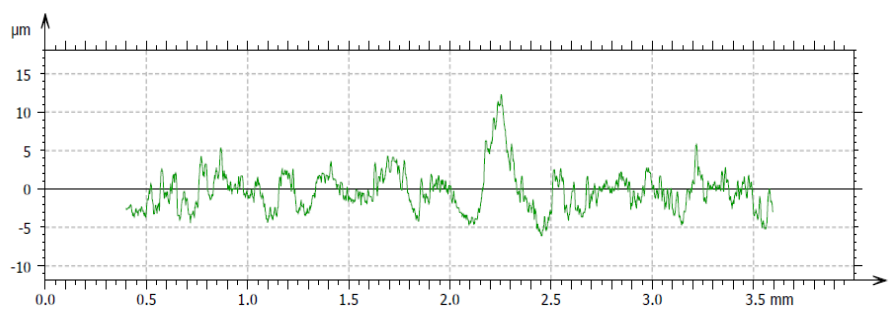

Fig. 5. (b) Surface roughness profile of Cu-Ni-P-W coated Al

This result indicates that the incorporation of sodium tungstate (W) particle into $\mathrm{Cu}-\mathrm{Ni}-\mathrm{P}$ coating results in relatively high surface roughness. This is to the presence of hard sodium tungstate (W) particles distributed into the nickel matrix. $\mathrm{Cu}-\mathrm{Ni}-\mathrm{P}$ and $\mathrm{Cu}-\mathrm{Ni}-\mathrm{P}-\mathrm{Wcomposite}$ coating presented in Fig.5 (a-b) clearly revealed that $\mathrm{Cu}-\mathrm{Ni}-\mathrm{P}$ coating have a smooth surface but $\mathrm{Cu}-\mathrm{Ni}-\mathrm{P}-\mathrm{W}$ coating are not smooth and contain rough surface when compared with $\mathrm{Cu}$ $\mathrm{Ni}-\mathrm{P}$ coating. These finding are consistent with the SEM image as show in Fig.3 (a-d).

\subsection{Friction and Wear}

The tribological contact of solid bodies results with two major phenomena namely friction and wear. Friction and wear measurements were carried out on $\mathrm{Cu}-\mathrm{Ni}-\mathrm{P}-\mathrm{W}$ specimen using pin-on-disc test facility.

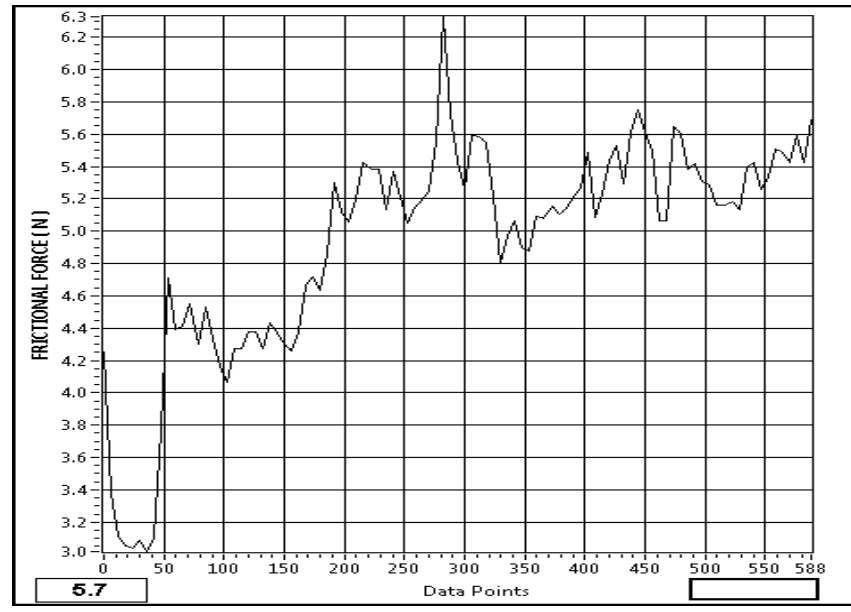

Fig.6. Friction profile of (a) $\mathrm{Cu}-\mathrm{Ni}-\mathrm{P}$ coated $\mathrm{Al}$

Fig.6 (a-b) shows the wear depth during the wear experiments at $100 \mathrm{~N}$ load with speed of $50 \mathrm{rpm}$ [19] for $\mathrm{Cu}-$ $\mathrm{Ni}-\mathrm{P}$ and $\mathrm{Cu}-\mathrm{Ni}-\mathrm{P}-\mathrm{W}$ coated $\mathrm{Al}$.

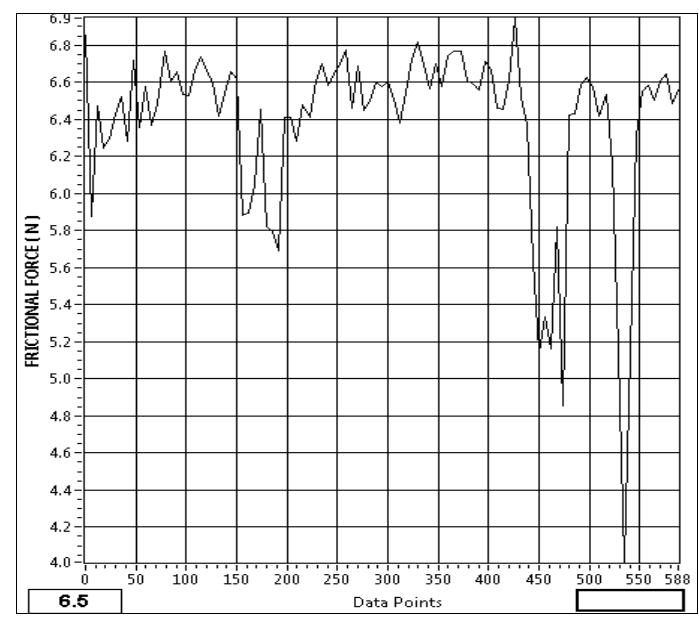

Fig.6. Friction profile of (b) Cu-Ni-P-W coated Al

It can be clearly seen that, with the increase in sodium tungstate $(\mathrm{W})$ content the coating shows more resistance to wear. This could be attributed to the solid solution strengthened by tungsten of nickel matrix.

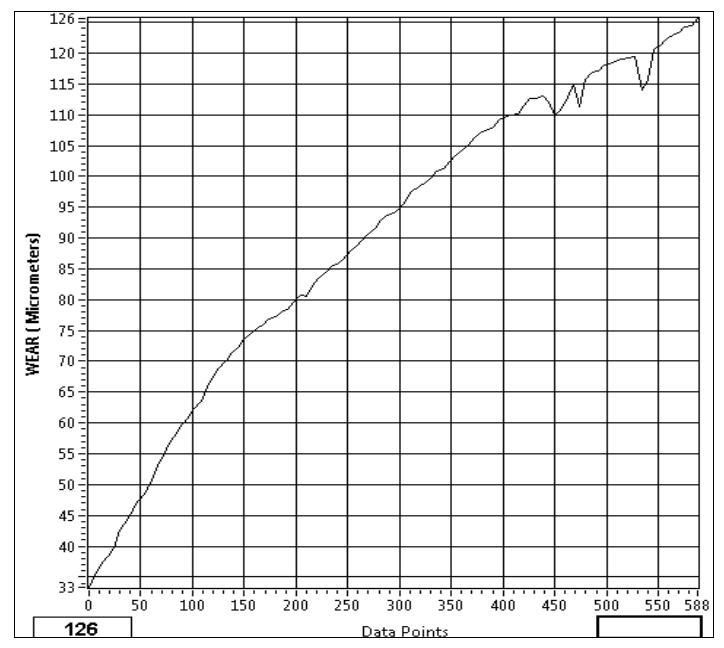

Fig.7. Wear rate of (a) Cu-Ni-P coated Al

Wear rate in these cases are in conjunction with the hardness values. The hardness of these coating is also seen to be increase with sodium tungstate content [15]. The mechanical wear of electroplating $\mathrm{Cu}-\mathrm{Ni}-\mathrm{P}$ deposit depends on the attractive force that operates between the atoms of nickel from the coating and aluminium from the counter disk. In all the cases the coefficient of friction is found to be high and further increases with the increase in applied normal load. Frictional coefficient is found to be in higher side as in plated coatings. The wear rates for electroplating of $\mathrm{Cu}-\mathrm{Ni}-\mathrm{P}$ and $\mathrm{Cu}-\mathrm{Ni}-\mathrm{P}-\mathrm{W}$ coated $\mathrm{Al}$ are as shown in Fig.7 (a-b). 


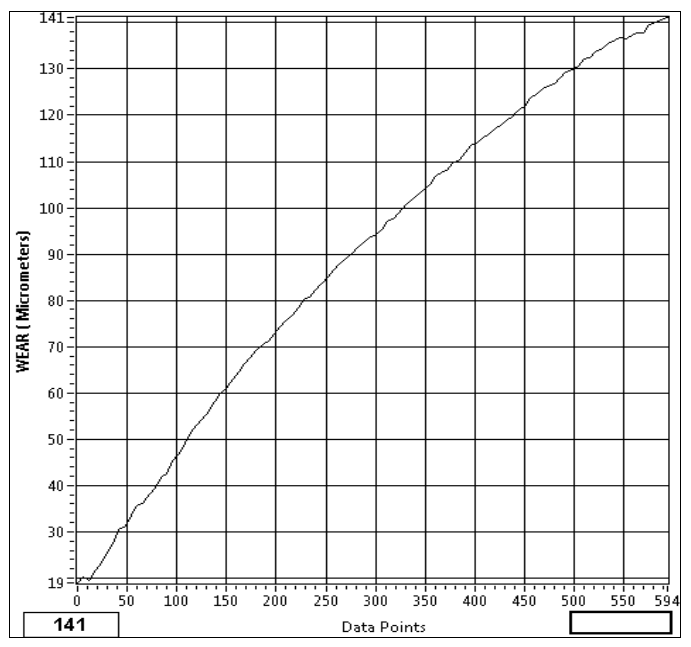

Fig.7. Wear rate of (b) Cu-Ni-P-W coated Al

The values from wear test suggest that the wear resistance increases with the sodium tungsten content which induces high hardness by solid solution strengthening [15]. In case of electroplating deposition, harder deposits are always found to be wearing out less than the softer deposits. The correlation between wear rate and the coefficient of friction of the composite coating and sodium tungsten concentration in plating solution, shows that the composite coating have lower wear rate and smaller coefficient of friction than that of $\mathrm{Cu}-\mathrm{Ni}-\mathrm{P}$ coating. It is interesting to note that the wear rate and coefficient of friction of $\mathrm{Cu}-\mathrm{Ni}-\mathrm{P}-\mathrm{W}$ composite coating decreases with increasing sodium tungsten in plating solution. Since the Fig.6 shows that clearly about the difference between $\mathrm{Cu}-\mathrm{Ni}-\mathrm{P}$ coated $\mathrm{Al}$ and $\mathrm{Cu}-\mathrm{Ni}-\mathrm{P}-\mathrm{W}$ coated Al. It is also observed that the $\mathrm{Cu}-\mathrm{Ni}-\mathrm{P}-\mathrm{W}$ based composite coatings exhibited lower wear rates when compared with pure $\mathrm{Cu}-\mathrm{Ni}-\mathrm{P}$ coatings under the dry sliding conditions.

\subsection{Micro Hardness}

The Vickers hardness test is performed for micro hardness of $\mathrm{Al} 6063$ substrate and composite coatings $\mathrm{Cu}-\mathrm{Ni}-\mathrm{P}$ and $\mathrm{Cu}-$ Ni-P-W with Al 6063.It can be seen that the micro hardness of composites coating were enhanced and varied significantly with the phosphorous and sodium tungstate (W) particles.

However the hardness of electroplating $\mathrm{Cu}-\mathrm{Ni}-\mathrm{P}$ increases with decrease of phosphorous content while the hardness of $\mathrm{Cu}-\mathrm{Ni}-\mathrm{P}-\mathrm{W}$ increase with the increase in sodium tungstate (W) content of the coating. We have seen that the hardness of the coating increase with the phosphorous content up to $6 \mathrm{~g} / \mathrm{l}$. The maximum hardness attained by this deposited coating was found to reach a value of $153 \mathrm{Hv}$.The hardness of the coating increases with the amount of sodium tungstate (W) content $80 \mathrm{ml} / \mathrm{L}$ in the deposit due to the solid solution strengthening of the nickel matrix by the dissolved sodium tungstate (W).

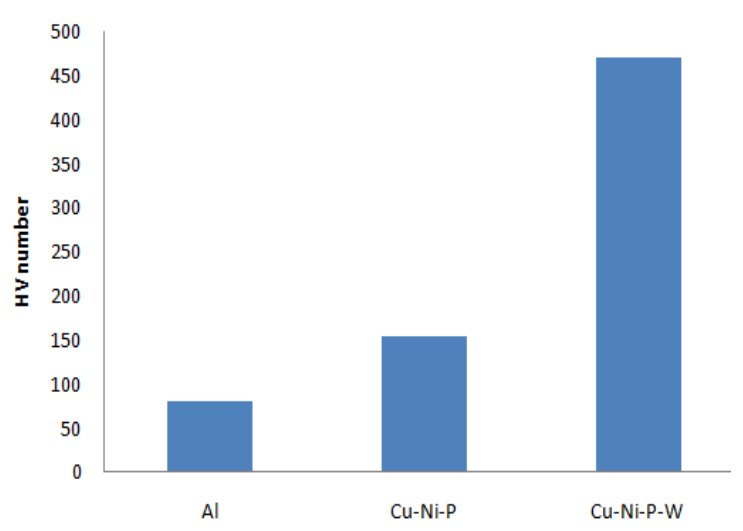

Fig. 8 Effect of sodium tungstate (W) particles on the micro hardness test

The electroplating of $\mathrm{Cu}-\mathrm{Ni}-\mathrm{P}$ coating and electroplating $\mathrm{Cu}$ Ni-P-W composite coating results in the increase of the coating hardness with a maximum hardness being achieved after the addition of sodium tungstate $(\mathrm{W})$ particles into $\mathrm{Cu}$ $\mathrm{Ni}-\mathrm{P}$ coating further increase the hardness of the coating was found the valve of $470 \mathrm{Hv}$. Cu-Ni-P-W hard particles leads to increase in the mechanical and physical properties of electroplating $\mathrm{Cu}-\mathrm{Ni}-\mathrm{P}$ composite coating.The sodium tungstate (W) composite deposit has higher micro-hardness and better abrasion resistance that of electroplating $\mathrm{Cu}-\mathrm{Ni}-\mathrm{P}$ composite electro-co deposition of sodium tungstate (W) along with $\mathrm{Cu}-\mathrm{Ni}-\mathrm{P}$ coating increases its hardness with the increase in the volume percent of sodium tungstate (W) in large.

\section{CONClusion ANd Future Scope}

$\mathrm{Cu}-\mathrm{Ni}$-P-W composite coatings with a range of sodium tungstate (W) particles addition were prepared by the electroplating method. Their mechanical properties including micro-hardness, wear resistance, the coefficient of friction and surface roughness were investigated. EDX and SEM analysis have shown that the morphological details. It is seen that there are many globular particles on the surface of the substrate with no surface damage. Also, the coating is dense and with no porosity were in plated $\mathrm{Cu}-\mathrm{Ni}-\mathrm{P}$ and $\mathrm{Cu}-\mathrm{Ni}-\mathrm{P}-\mathrm{W}$ coating. The micro-hardness of Cu-Ni-P-W (W for $80 \mathrm{gm} / \mathrm{L}$ ) composite coatings can reach approximately $470 \mathrm{HV}$ compared to $153 \mathrm{HV}$ of $\mathrm{Cu}-\mathrm{Ni}-\mathrm{P}$ coating, the microhardness of the composite coating increased with increasing amount of sodium tungstate $(\mathrm{W})$ particles in the composite coating. similarly, increase the wear resistance and reduced friction coefficient due to increase in hardness. The improvement is attributed to the strengthening effect of sodium tungstate (W) dispersion in the Al-substrate. From this study it is concluded that the $\mathrm{Cu}-\mathrm{Ni}-\mathrm{P}-\mathrm{W}$ composite coatings shows better micro- 
hardness, wear resistance, less coefficient of friction and surface roughness.

\section{REFERENCES}

[1] W. S. Miller, L. Zhuang, J. Bottema, A. J. Wittebrood, P. De Smet, A. Haszler, and A. Vieregge, "Recent development in aluminium alloys for the automotive industry," Mater. Sci. Eng., vol. 280, no. 1, pp. 37 49, 2006

[2] M. Surender, B. Basu, and R. Balasubramaniam, "Wear characterization of electrodeposited Ni-WC composite coatings," Tribol. Int., vol. 37, pp. 743-749, 2004

[3] S. Pradeep Devaneyan and T. Senthilvelan, "Electro co-deposition and characterization of $\mathrm{SiC}$ in nickel metal matrix composite coatings on aluminium 7075," Procedia Eng., vol. 97, pp. 1496-1505, 2014

[4] D.S.Stoychev, E.A.Stoyanova and St. Rashkov, "Deposition of thin tin coatings on aluminium alloys", institute of physical chemistry, bulgarian academy of sciences, sofia 1040 (bulgaria), vol. 23, pp. 127141,1984

[5] R. Nair, W. Jiang, and P. Molian, "Synthesis of diamond-like carbon coatings on aluminum 6061 T-91 substrates by laser sintering of ultrananocrystalline diamond powders," Surf. Coatings Technol., vol. 202, no. 13, pp. 2935-2944, 2008

[6] S. T. Aruna, V. K. W. Grips, and K. S. Rajam, "Ni-based electrodeposited composite coating exhibiting improved microhardness , corrosion and wear resistance properties," vol. 468, pp. 546-552, 2009

[7] K. H. Hou, M. D. Ger, L. M. Wang, and S. T. Ke, "The wear behaviour of electro-codeposited $\mathrm{Ni}-\mathrm{SiC}$ composites," vol. 253, pp. 994-1003, 2002

[8] S. Wang and W. J. Wei, "Kinetics of electroplating process of nanosized ceramic particle / Ni composite," vol. 78, pp. 574-580, 2003

[9] L. Chen, L. Wang, Z. Zeng, and J. Zhang, "Effect of surfactant on the electrodeposition and wear resistance of $\mathrm{Ni}-\mathrm{Al} 2 \mathrm{O} 3$ composite coatings," vol. 434, pp. 319-325, 2006

[10] L. Wang, Y. Gao, H. Liu, Q. Xue, and T. Xu, "Effects of bivalent Co ion on the co-deposition of nickel and nano-diamond particles," vol. 191, pp. 1-6, 2005

[11] L. Chen, L. Wang, Z. Zeng, and T. Xu, "Influence of pulse frequency on the microstructure and wear resistance of electrodeposited $\mathrm{Ni}-\mathrm{Al} 2$ O 3 composite coatings," vol. 201, pp. 599-605, 2006

[12] N. K. Shrestha, T. Takebe, and T. Saji, "Effect of particle size on the co-deposition of diamond with nickel in presence of a redox-active surfactant and mechanical property of the coatings," vol. 15, pp. 1570 1575,2006

[13] D. J. R. U, "Electrochemistry in nanoparticle science," vol. 1, pp. 186192, 2002

[14] S. Duari, A. Mukhopadhyay, T. K. Barman, and P. Sahoo, "Study of Wear and Friction of Chemically Deposited Ni-P-W Coating under Dry and Lubricated Condition," Surfaces and Interfaces, 2017.

[15] M. Palaniappa and S. K. Seshadri, "Friction and wear behavior of electroless Ni-P and Ni-W-P alloy coatings," Wear, vol. 265, no. 5-6, pp. $735-740,2008$

[16] A. Luiz, M. Oliveira, J. D. Costa, M. B. De Sousa, J. Jailson, N. Alves, A. Regina, N. Campos, R. Alexandre, C. Santana, and S. Prasad, "Studies on electrodeposition and characterization of the $\mathrm{Ni}-\mathrm{W}-\mathrm{Fe}$ alloys coatings," J. Alloys Compd., vol. 619, pp. 697-703, 2015

[17] K. A. Kumar, G. P. Kalaignan, and V. S. Muralidharan, "Direct and pulse current electrodeposition of $\mathrm{Ni}-\mathrm{W}-\mathrm{TiO} 2$ nanocomposite coatings," Ceram. Int., vol. 39, no. 3, pp. 2827-2834, 2013

[18] Y. Wang, W. Chen, A. Shakoor, R. Kahraman, W. Lu, B. Yan, and W. Gao, "Ni-P-TiO2 Composite Coatings on Copper Produced by SolEnhanced Electroplating," vol. 9, pp. 4384-4393, 2014
[19] M. F. He, W. Bin Hu, C. Zhong, J. F. Weng, B. Shen, and Y. T. Wu, "Effect of wear conditions on tribological properties of electrolesslydeposited Ni-P-Gr-SiC hybrid composite coating," Trans. Nonferrous Met. Soc. China (English Ed.), vol. 22, no. 10, pp. 2586-2592, 2012

[20] Tanveer Ahmad Dar, Arpana Agrawal and Pratima Sen," Role of Ni Doping on Structural, Electronic and Transport Properties of ZnO Thin Films", IJSRPAS, Vol-3, Issue 2, pp 9-11, 2015

\section{AUTHORS PROFILE}

Mr. M.Karunakaran pursed B. Tech. Mechanical Engineering from Bharathiar College of Engineering \& Technology, Karaikal, Puducherry in 2009 and pursed M.Tech. \& pursuing Ph.D. in the Department of Mechanical Engineering, Pondicherry Engineering College, Puducherry in 2011 \& 2018. He is currently working as Assistant Professor in Department of Mechanical Engineering from Sri Ganesh College of Engineering and Technology, Pondicherry since 2013. He has published three research papers in international journals and conferences. His main research work focuses on Material development, Composite materials, Electroplating, Nano coating and thin film coating. He has seven years of teaching experience and 5 years of research experience.

Dr M.Pugazhvadivu pursed PhD from Pondicherry Engineering college, Puducherry in 2010. She is currently working as Professor in the Department of Mechanical Engineering, Pondicherry Engineering college, Puducherry since 1995 . She is a recipient of Young Scientist award from Department of Science \& Technology, New Delhi in 2005. She has projects from Department of Science \& Technology (DST). She is a life time member of Indian Society Technology Education and Indian Society Mechanical Engineers. She has published more than 20 research papers in reputed international journals and conferences. Her main research work focuses on Alternative fuels, IC engine performance, Nano coating in IC engine and Composite materials. She has more than 22 years of teaching experience and 15 years of Research Experience.

Mr V.Gunasegaran pursed Bachelor of Technology and Master of Technology from Department of Mechanical Engineering, Pondicherry Engineering college, Puducherry in year $2006 \& 2011$. He is currently pursuing Ph.D. and currently working as Assistant Professor in School of Mechanical Sciences, BSA Crescent Institute of Science and Technology, Chennai-48 since 2011. He has published two

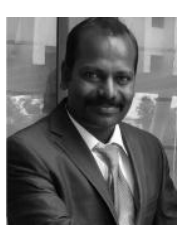
research papers in reputed international journals and five conferences. His main research work focuses on material development, Composites, Vibrational analysis and condition monitoring. He has 7 years of teaching experience and 4 years of Research Experience.

Mr G.Gowtham pursed Bachelor of Technology from Department of Mechanical Engineering, Ganesh college of engineering and technology, Puducherry in year 2016. He is currently working as Quality engineer, Department of Quality, Easun-MR Tap Changers Pvt. Ltd., Puducherry since 2016. He has published one research paper and three conferences. His main research work focuses on material

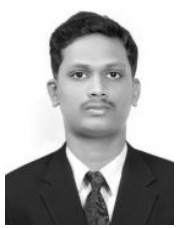
development, Composites, Nano coating and electrodeposition. He has 2 years of industrial experience and 1 year of Research Experience. 